\title{
Experience of Using Microteaching to Teach Postgraduates on How to Conduct a Workshop
}

\author{
Suguna, E. ${ }^{1} \&$ Dongre, A.R. ${ }^{2}$
}

\begin{abstract}
Introduction: There exists a gap between the existing postgraduate curriculum of imparting teachinglearning methods and their expected role as a trainer in future. We wanted to share the approach of using microteaching and discuss the facilitators' reflection of using teaching-learning methods.

Methods: Three final year postgraduates were asked to conduct a half-day workshop for sixteen participants (medical interns and junior postgraduates) on study designs in Epidemiology following the principles of microteaching. The facilitators' reflections were obtained using Pendleton's model. Manual content analysis was done with the qualitative data.
\end{abstract}

Results \& Conclusion: Five categories emerged from their reflection namely, pre-planning, physical arrangements, session planning, session delivery, self-reflection and constraints faced. Hence using microteaching as a method to teach postgraduates on how to conduct a workshop was successful in empowering post-graduates with medical education technology and reflective practices.

\section{Introduction}

Medical Council of India (MCl) envisions that at the end of the postgraduate training the student should acquire skills in Teaching-Learning methods in addition to the subject content (Medical Council of India, 2011). Pedagogy has been used as an integral part of summative assessment for postgraduates in Community Medicine (Pondicherry University Postgraduate Medical Education (Amendment) Syllabus \& Regulations, 2008).

Another major aim of postgraduate medical education is that the trainee eventually becomes a trainer for medical students and other health care professionals.

\footnotetext{
${ }^{1}$ Assistant Professor

${ }^{2}$ Professor \& Head

Department of Community Medicine,

Sri ManakulaVinayagar Medical College and Hospital,

Kalitheerthalkuppam, Pondicherry - 605107

Corresponding Author:

Suguna Elayaperumal,

Assistant Professor,

Department of Community Medicine,

Sri ManakulaVinayagar Medical College and Hospital,

Kalitheerthalkuppam, Pondicherry - 605107

E-mail:drsuguna.e@gmail.com
}

Hence there exists a gap between the existing postgraduate (PG) curriculum and their expected role in future. Therefore we tried to bridge the gap through microteaching. Microteaching is a teacher training technique for learning teaching skills.

It employs real teaching situation for developing skills and helps to get deeper knowledge regarding the art of teaching. It involves the steps of "plan, teach, observe, re-plan, re-teach and re-observe" (Ramesh, 2013).

In the Department of Community Medicine, Sri Manakula Vinayagar Medical College and Hospital, Pondicherry, we made an attempt to mainstream Teaching-Learning methods in postgraduate curriculum.

Postgraduates were exposed to their routine curriculum and to some teaching-learning skills followed by hands-on exposure as a workshop facilitator under faculty supervision. Later, supervising faculty discussed feedback with the postgraduates and asked them to reflect on their performance as a facilitator.

Reflection is a cognitive process of understanding and evaluating the meaning of an experience within the context of one's previous experience, previous and existing knowledge, beliefs, and assumptions and 
allows enabling improvement for future practice (Lucas et al., 2016). The purpose of the present paper is to share the approach of using microteaching and discuss the facilitators' reflection of using teaching-learning methods.

\section{Methods}

Study setting: The study was conducted in the Department of Community Medicine, Sri Manakula Vinayagar Medical College and Hospital, Pondicherry.

Study design: qualitative study (using openended questions) for reflection of facilitators.

Study duration: Two months (June - July 2013)

Study population and sample size: Six junior postgraduates and ten medical interns in the Department of Community Medicine were the study participants. Three final year postgraduates were the facilitators.
Brief procedure: Nine postgraduates in the Department of Community Medicine were exposed to basic course on Epidemiology for a total duration of 32 hours. The sessions were facilitated by trained faculties. Thereafter, the three final year postgraduates were asked to conduct a half-day workshop for the sixteen participants on study designs in Epidemiology. They were instructed to follow the principles of microteaching and plan an interactive workshop. The postgraduates were asked to prepare a session plan and discuss it with the three supervising faculties. At the end of the workshop, two faculties interacted with the three postgraduate facilitators to discuss their reflections by following the Pendleton's model. Ethical principles in data collection and analysis were followed. Manual content analysis was done with the qualitative data.

\section{Results}

Six categories emerged from the qualitative data (Table 1).

\section{Table 1: Content analysis of the qualitative data obtained from interviewing the facilitators $(n=3)$}

\begin{tabular}{lll}
\hline S.no & Categories & \\
\hline 1 & Pre- planning & $\begin{array}{l}\text { Assisting in conducting the workshops in the previous years helped us to organize } \\
\text { well. } \\
\text { I have observed speakers in other workshops about set induction to arouse the } \\
\text { interest of the audience. }\end{array}$ \\
\hline 2 & $\begin{array}{l}\text { Physical } \\
\text { arrangements }\end{array}$ & $\begin{array}{l}\text { We planned to provide refreshments as it would raise the energy levels of the } \\
\text { audience and would make them feel friendlier with us. } \\
\text { We tried to change their seating positions as we wanted to break their comfort zones. }\end{array}$ \\
\hline 3 & $\begin{array}{l}\text { Session } \\
\text { planning }\end{array}$ & $\begin{array}{l}\text { Working as a team helped us to avoid mistakes. } \\
\text { We knew our strengths and weaknesses so each of us split the topics which were } \\
\text { comfortable for us. } \\
\text { We should have prepared more for the workshop and improved our confidence } \\
\text { levels. }\end{array}$ \\
\hline 4 & Session delivery & $\begin{array}{l}\text { I felt that the whole process was thrilling and quite good. } \\
\text { I made sure that the slides were not similar to the seminar mode. } \\
\text { I was more comfortable with chalk and board than withPower point. }\end{array}$ \\
\hline 5 & Self- reflection & $\begin{array}{l}\text { The workshop was more challenging for me and I enjoyed it more. } \\
\text { I was thorough with the topic as we have been having seminars, journal } \\
\text { presentations and PG learning activities. } \\
\text { In the workshop I felt responsible to teach and deliver the contents as Istood there as } \\
\text { a facilitator. } \\
\text { I am fully satisfied; I think that I have done justice to my part. } \\
\text { Peer criticism helped us to improve our presentation skills. }\end{array}$ \\
& $\begin{array}{l}\text { I would like to have more interaction with the audience. } \\
\text { I will organize my content more clearly in future. } \\
\text { I will give clear instructions to the audience about filling the feedback forms. } \\
\text { I will work on time management. }\end{array}$ \\
\hline 6 & Constraints
\end{tabular}

They were: 1) Pre-planning: The facilitators felt that assisting in conducting the workshops in the previous years helped them in organizing and well execution of the content. 2) Physical arrangements: Proper seating arrangements and refreshments enabled conducive learning environment for the participants. 3) Session planning: The PGs expressed that team work and knowing each other's strengths and weaknesses helped in good session planning. 
4) Session delivery: Facilitating postgraduates felt 'thrilled' and 'confident' during content delivery. 5) Self-reflection: The facilitators mentioned that, "During the workshop I felt responsible to teach and deliver the content, as I stood there as a facilitator". 6) Constraints: Lack of proper time management, minimal interaction with the audience and lack of organization of content were identified as the constraints for the implementation.

\section{Discussion}

The major findings of the study shows that the experiences of the facilitating postgraduates in microteaching could be grouped under six categories namely, pre-planning, physical arrangements, session planning, session delivery, self-reflection and constraints faced. These categories were in alignment to the major steps of microteaching process namely "plan, teach, observe, re-plan, re-teach and re-observe".

The present study expresses that microteaching has given the opportunity to postgraduates to apply in practice the pedagogical theories. The conventional PG teaching method involves only transfer of knowledge from seniors and faculties with no emphasis on reflection and feedback on performances. Studies have shown that there is a felt need among students to translate the knowledge gained into practice to get feedback on their actual performance. They also acknowledged the great benefits of reflection through microteaching as compared to the conventional PG teaching method (Ismail, 2011). A similar study done on qualitative exploration of the $P G$ students experience of conducting a microteaching session was grouped under two themes namely, presenting skills and use of teaching aids (Sawant et al., 2015).

The study being a qualitative exploration of the self-reflection of the facilitating postgraduates' about the approach, process of microteaching and feedback was the major strength of the study. The major challenges of conducting a similar study are the skills of the faculties in transferring Teaching-learning methods to postgraduates and dedicated time for reflection and constructive feedback.

\section{Conclusion}

The present study found that using microteaching as a method to teach postgraduates on how to conduct a workshop was successful and was well received by the participants. Hence empowering postgraduates with medical education technology and reflective practices early during their course are likely to produce skilled and competent medical teachers for future as envisioned by the Medical Council of India.

\section{References}

Garg, R. \& Gupta, S. (2011) Are we really producing public health experts in India? Need for a paradigm shift in postgraduate teaching in community medicine, Indian Journal of Community Medicine, 36, 2, pp. 93-97.

Ismail, S.A.A. (2011) Student teachers microteaching experiences in a preservice English teacher education program, Journal of Language Teaching and Research, 2, 5, pp.1043-1051.

Pondicherry University Postgraduate Medical Education (Amendment) Syllabus \& Regulations (2008) Available at: http://www.pondiuni.edu.in/sites/default/files/d ownloads/MDMS_Medical_-2008.pdf.

Remesh A. (2013) Microteaching, an efficient technique for learning effective teaching, Journal of Research in Medical Sciences, 18, 2, pp. 158-163.

Sawant V. \& Bansode M.K. (2015) Microteaching of post graduate medical students - A modern innovation in teaching and learning, International Journal of Scientific Research, 10, 4, pp. 468-470.

Tsingos-Lucas, C., Bosnic-Anticevich, S., Schneider, C.R. \& Smith, L. (2016) The effect of reflective activities on reflective thinking ability in an undergraduate pharmacy curriculum, American Journal of Pharmaceutical Education, 80, 4, pp.1-12.

Medical Council of India (2011) Vision 2015, New Delhi: Medical Council of India, [Online] Available http://www.mciindia.org/tools/announcement/ MCl_booklet.pdf. [Accessed Jan 2017] 